\title{
A simple external tissue expansion technique based on viscoelastic properties of skin to attain direct closure of a large scalp defect: A case report
}

\author{
Bandikatla Venkata Ratnam \\ Department of Plastic Surgery, NMCS Hospital, Abu Dhabi, UAE
}

Address for correspondence: Dr. Bandikatla Venkata Ratnam, Department of Plastic Surgery, NMCS Hospital, PO Box - 6222, Electra

Street, Abu Dhabi, UAE. E-mail: bvratnam@emirates.net.ae

\section{ABSTRACT}

Background: Direct closure of large scalp defects is not an easy task. Complicated flap designs or staged surgeries over a period of 6 months are often required. A case of a large scalp defect that was closed directly in 3 months by applying a simple external tissue expansion technique is presented in this report. Patient Profile: A 28-year-old male patient presented with a painful swelling of about $13 \mathrm{~cm} \times$ $14 \mathrm{~cm}$, on frontoparietal scalp. A biopsy done elsewhere reported it to be a neurofibroma. He sought tumour excision and scalp defect coverage by hair-bearing scalp in a period of less than 5 months. Materials and Methods: The tumour was excised and the adjacent scalp was gradually expanded with the help of an external fixator. The patient had immediate pain relief after excision. The goal of repairing scalp defect and replacing it with hairy scalp was achieved in 3 months. Conclusion: The mechanical device required for this technique is relatively easily accessible. It is not difficult to achieve desirable outcomes, and the same can be applied to large wounds on other areas.

\section{KEY WORDS}

Closure of large scalp defects; external tissue expansion; large scalp defects' closure; scalp tissue expansion

\section{INTRODUCTION}

$\mathrm{t}$ is not easy to close large scalp defects because of its unyielding nature. Complex flap designs and multiple surgeries over a period of 6 months are often needed. A case of a scalp defect that was directly closed in a period of 3 months by applying a simple external expansion technique is presented herein.

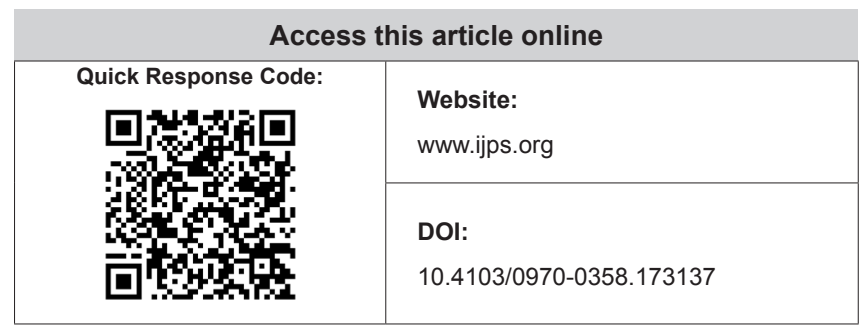

\section{Patient profile}

A 28-year-old male patient presented with a painful neurofibroma of about $13 \mathrm{~cm} \times 14 \mathrm{~cm}$ size on frontoparietal scalp. The tumour grew to the present size in 7 years. The growth was rapid in the previous 4 months. The patient wanted early excision of the tumour and

\footnotetext{
This is an open access article distributed under the terms of the Creative Commons Attribution-NonCommercial-ShareAlike 3.0 License, which allows others to remix, tweak, and build upon the work non-commercially, as long as the author is credited and the new creations are licensed under the identical terms.
}

For reprints contact: reprints@medknow.com

How to cite this article: Ratnam BV. A simple external tissue
expansion technique based on viscoelastic properties of skin to
attain direct closure of a large scalp defect: A case report. Indian J
Plast Surg 2015;48:309-12. 
coverage of the defect with hair-bearing scalp in a period of less than 5 months. He refused skin grafting and scalp expansion by balloon tissue expanders.

There was a slightly warm, mildly tender, flat, soft tissue tumour of about $13 \mathrm{~cm} \times 14 \mathrm{~cm} \times 1.5 \mathrm{~cm}$ size occupying the frontoparietal region of the scalp [Figures 1 and 2]. It was not attached to the calvarium. There was no significant enlargement of regional lymph nodes. And, no similar tumours or other abnormalities were found elsewhere in the body. Radiological investigation revealed no involvement of the underlying bone. Biopsy, done in an outside facility, had reported it as 'discrete cutaneous neurofibroma'.

\section{MATERIALS AND METHODS}

The tumour was excised under local anaesthesia with a margin of about $1 \mathrm{~cm}$ of normal-looking tissue around it [Figure 3]. Sterile Kirschner wires ( $0.9 \mathrm{~mm}$ in diameter) were

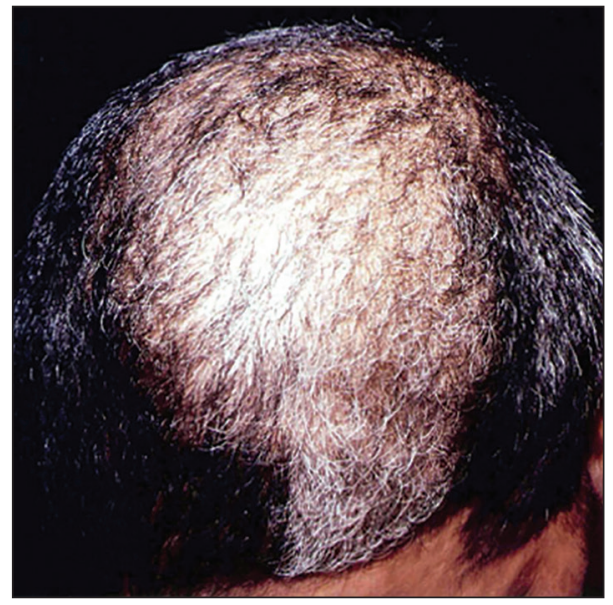

Figure 1: Grey hair over the scalp tumour

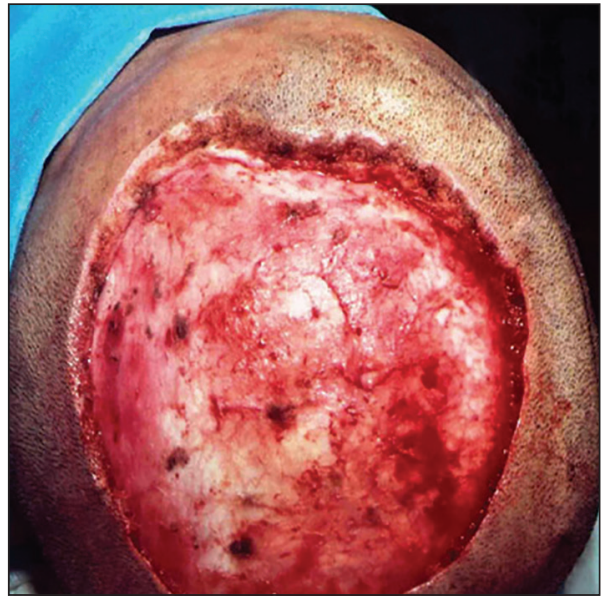

Figure 3: The excisional defect in the scalp passed into the scalp intradermally on two sides of the wound. The projecting ends of the wires were connected by specialized screws, called 'distracters'. This completed assembling of the rectangular frame of the external fixator, called 'Joshi's External Stabilization System', [JESS Research and Development Council, 10, ONGC Colony, Bandra (W), Mumbai 400050, India] [Figure 4]. One full turn of the knobs on the 'distracters' moves Kirschner wires of the frame by $1 \mathrm{~mm}$ with the K-wires applying traction on the adjacent scalp. After every manoeuver, the wound was dressed and the sharp ends of the Kirschner wires were covered with sterile surgical pads. This was done on alternate days.

The turning of the knobs was made to just short of resistance, and stopped before the patient had discomfort [Figure 5]. With each act of turning of the distracters' knobs traction was applied on the adjacent scalp, which got expanded by about $1 \mathrm{~mm}$. Within a period of 3 months, the wound edges had met each

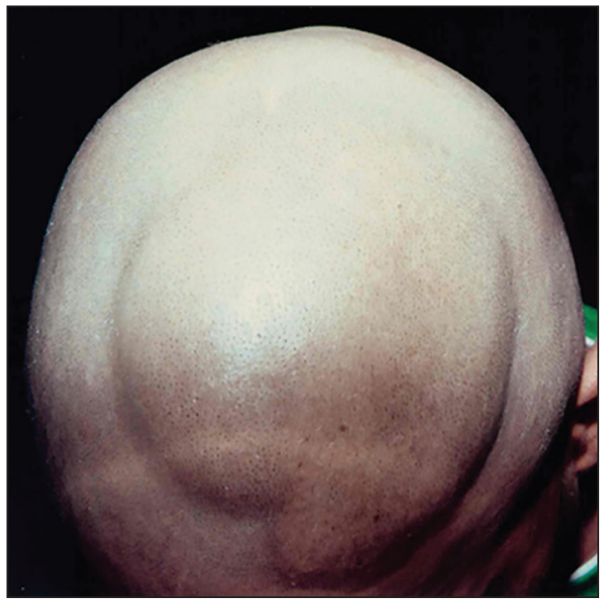

Figure 2: The scalp tumour with the overlying faint greyish-brown maculae

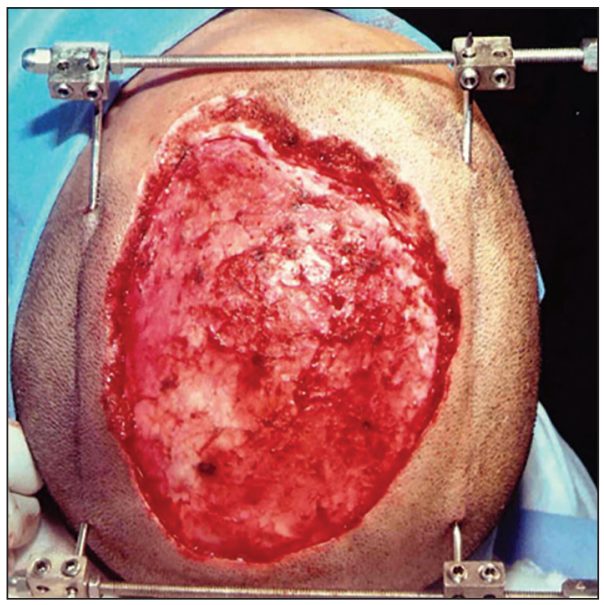

Figure 4: The external fixator assembly around the defect. Note that the ends of K-wires were bent away from skin surface for obtaining clearance for the external fixator 
other [Figure 6]. Then the wound was directly closed with sutures. The frame was removed after 2 days [Figure 7]. The sutures were removed on the tenth day. The entire treatment was rendered on outpatient basis. The result was stable at 2 years' post-operative period [Figure 8].

\section{RESULT}

The patient became pain free immediately after the excision of the tumour. Histopathological report confirmed the diagnosis of neurofibroma, with complete marginal clearance. The part of the scalp containing the tumour was replaced by healthy scalp and natural hair in a period of about 3 months [Figure 8].

\section{DISCUSSION}

\section{Viscoelastic properties of skin}

The skin's viscoelastic properties are as follows: 'creep' and 'stress relaxation'. Creep implies that the

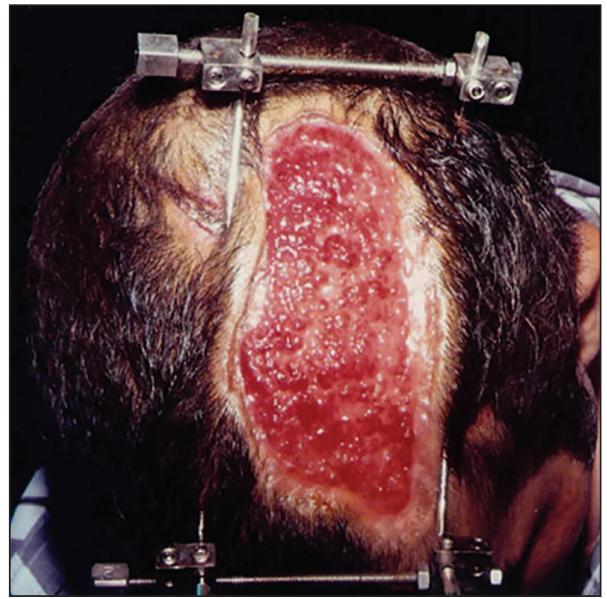

Figure 5: External tissue expansion in progress

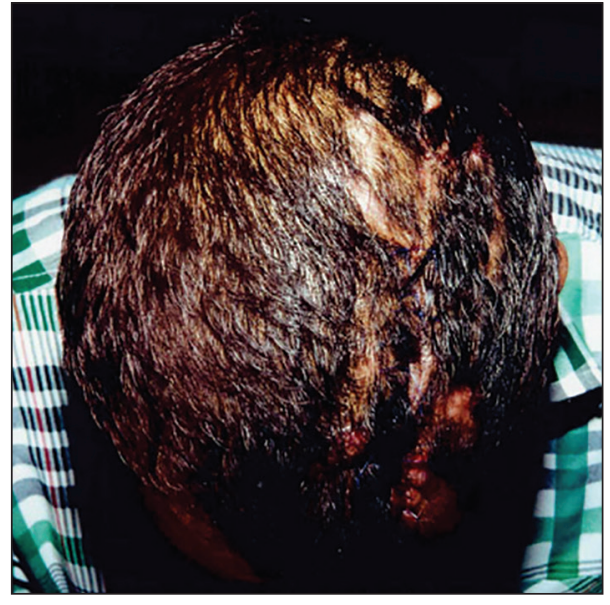

Figure 7: The external fixator was removed skin continues to stretch as long as the stretching force is applied. Stress relaxation implies that if a piece of skin is stretched and the stretching force is kept constant, with time, the force required to keep it stretched gradually decreases. ${ }^{[1]}$ The tensile strength was described by Levenson et al. ${ }^{[2]}$ in 1965 . It denotes that the collagen turnover and cross-linkage in the wound result in the tensile strength of up to $80 \%$ of normal tensile strength, by about 12 weeks after the closure. It implies that if a wound is directly closed and is stable at 12 weeks, it will not stretch back or reopen again. In the reported case, the skin's viscoelastic properties helped expansion of the neighbouring scalp externally. The gain was about $1.5-2 \mathrm{~mm}$ of extra scalp per day.

A variety of skin stretching devices ${ }^{[3-13]}$ are used to attain direct closure of surface soft tissue defects. However, they are either complicated, expensive, or for single use

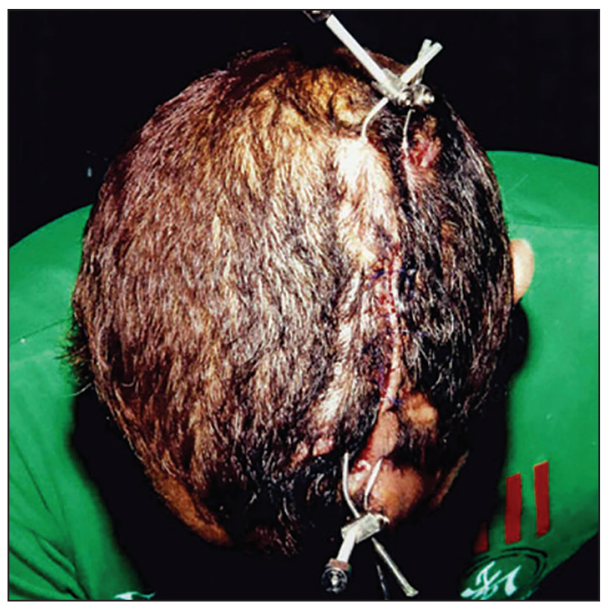

Figure 6: External tissue expansion completed. Note the normal scalp and natural hair on either side of the frame

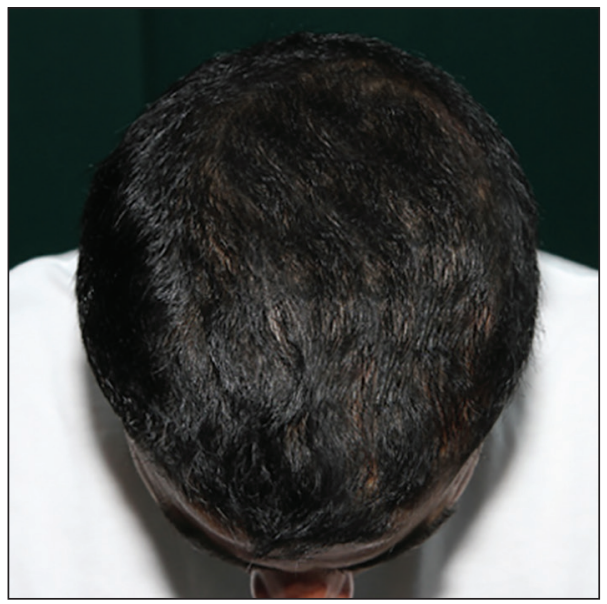

Figure 8: The result at 2 year follow-up 
only. Most are not easily available. The technique applied in this report is simple and easy to learn. The device used is less expensive, reusable (thus, reducing the treatment costs further), and easily available throughout India. The disadvantages of this technique are minor. They include skin puncture site marks which are better than the end results of the procedures such as skin grafting and flap coverage which make this technique worthy of a fair trial.

\section{CONCLUSION}

To the author's knowledge, the closure of such a large defect in the scalp by applying external tissue expansion technique has not been reported earlier. This technique can be applied to close surface soft tissue defects in other parts of the body as well. This is especially so when conventional techniques are either not helpful or refused by the patients.

\section{Acknowledgement}

The author gratefully acknowledges the patient for his kind cooperation during the treatment process; Padma Sree Dr BR Shetty, our CEO \& MD and Dr CR Shetty, our Group Medical Director for their encouragement and support; and Dr Bandikatla Thejaswi, Dept of Geriatric Medicine, Weill Cornell Medical College, New York City, NYC, USA and Ms B. Sudeepthi, Medical Student, Kasturba Medical College, Manipal, India, for their help in preparation of the manuscript.

\section{Financial support and sponsorship}

Nil.

\section{Conflicts of interest}

There are no conflicts of interest.

\section{REFERENCES}

1. Gibson T. Physical properties of skin. In: McCarthy JG, editor. Plastic Surgery. Philadelphia: WB Saunders; 1990. p. 207-20.

2. Levenson SM, Geever EF, Crowley LV, Oates JF $3^{\text {rd }}$, Berard CW, Rosen H. The healing of rat skin wounds. Ann Surg 1965;161: 293-308.

3. Hirshowitz B, Baum E, Har-Shai Y. A skin-stretching device for the harnessing of the visco-elastic properties of skin. J Plast Reconstr Surg 1993;92:260-70.

4. Mingli Z, Dawei W, Lan H. The application of skin external expander to postburn advanced scar contracture. Plast Reconstr Surg 1995;96:1600-7.

5. Blomqvist G. ETE (external tissue expansion): A new method for external tissue extension. Ann Chir Plast Esthet 1996;41:577-81.

6. Subramania KI, Mohit S, Sasidharan PR, Abraham MK, Arun P, Kekatpure V. 'Sure closure'-skin stretching system, our clinical experience. Indian J Plast Surg 2005;38:132-7.

7. Lapid O. An improvised wound closure system. J Trauma 2006;60:910-4.

8. Lasheen $\mathrm{AE}$, Saad K, Raslan M. External tissue expansion in head and neck reconstruction. J Plast Reconstr Aesthet Surg 2009;62:e251-4.

9. Hirshowitz B, Lindenbaum E, Har-Shai Y. A skin-stretching device for the harnessing of the viscoelastic properties of skin. Plast Reconstr Surg 1993;92:260-70.

10. Kocialkowski A, Marsh DR, Shackley DC. Closure of the skin defect overlying infected non-union by skin traction. Br J Plast Surg 1998;51:307-10.

11. Cohen $\mathrm{BH}$, Cosmetto AJ. The suture tension adjustment reel: A new device for the management of skin closure. J Dermatol Surg Oncol 1992;18:112.

12. Ger R, Evans JT, Oddsen R. A clinical trial of wound closure of constant tension approximation. Am J Surg 1996;171:331-4.

13. Carmel NN, Silberman A, Li MS, Li YZ. The TopClosure $₫ 3 S$ System, for skin stretching and a secure wound closure. Eur J Plast Surg 2012;35:533-43. 